\title{
Analisis Garis Pantai Ladong Aceh Besar Tahun 2011-2015 dengan Menggunakan Sistem Informasi Geografis
}

\author{
Chasandra Faradila a*, Ichsan Setiawan a, Edy Miswar ${ }^{\mathrm{b}}$ \\ a Program Studi Ilmu Kelautan, Fakultas Kelautan dan Perikanan, Universitas Syiah Kuala, Banda Aceh, Aceh-Indonesia \\ ${ }^{b}$ Program Studi Pemanfaatan Sumberdaya Perikanan, Fakultas Kelautan dan Perikanan, Universitas Syiah Kuala, Banda Aceh, Aceh-Indonesia \\ * Penulis koresponden. Tel.: +62-822-4262-7477 \\ Alamate-mail: chasandra5@gmail.com
}

Diterima (received) 10 Januari 2017; disetujui (accepted) 15 Maret 2017; tersedia secara online (available online) 17 Maret 2017

\begin{abstract}
The purpose of this study was to determine shoreline change along the coast of Ladong, Mesjid Raya subdistrict, Aceh Besar district, Aceh province in the 5 years period started from the year 2011, 2012, 2013, 2014 and 2015. Ground check was implemented in August 2016. This study utilized Geographic Information System technology (GIS), remote sensing and by utilizing Google Earth to capture aerial photo. The result from this research showed that each year the shoreline changes, either it was abrasion or accretion. In 2011-2012 the value of abrasion reached 1.1 ha and the value of accretion reached 0.5 ha. In 2012-2013 the value of abrasion reached 0.3 ha and the value of accretion reached 0.8 ha. In 2013-2014 the value of abrasion reached 1.2 ha and the value of accretion reached 0.2 ha. In 2014-2015 the value of abrasion reached 0.2 ha and the value of accretion reached 1.5 ha. The value of the annual abrasion average reached 0.56 ha and the value of the accretion was 0.58 ha. The largest abrasion happened in 2013-2014 which reached 1.2 ha. The total value of 5 year abrasion was 2.8 ha and the total value of accretion was recorded 2.9 ha. The process of abrasion and accretion also caused a change of the length of Ladong's coastline every year, and the river estuary was one of the reasons that caused abrasion or accretion
\end{abstract}

Keywords: accretion; abrasion; Google earth

\begin{abstract}
Abstrak
Tujuan penelitian ini adalah untuk mengetahui perubahan garis pantai di sepanjang Pantai Ladong, Gampong Ladong Kecamatan Mesjid Raya, Kabupaten Aceh Besar Provinsi Aceh dalam kurun waktu 5 tahun yang dimulai dari tahun 2011, 2012, 2013, 2014, dan 2015. Survei lapangan dilaksanakan pada bulan Agustus 2016. Penelitian ini memanfaatkan teknologi Sistem Informasi Geografis (SIG), penginderaan jauh dan dengan memanfaatkan Google Earth untuk pengambilan data foto udara. Hasil penelitian ini menunjukan bahwa setiap tahunnya pantai mengalami perubahan, baik itu abrasi maupun akresi. Tahun 2011-2012 nilai abrasi yang terjadi mencapai 1,1 Ha dan nilai akresi mencapai 0,5 Ha. Tahun 2012-2013 nilai abrasi yang terjadi mencapai 0,3 Ha dan nilai akresi yang terjadi mencapai 0,8 Ha. Tahun 2012-2013 nilai abrasi yang terjadi mencapai 1,2 Ha dan nilai akresi mencapai 0,2 Ha. Tahun 2014-2015 nilai abrasi yang terjadi mencapai 0,2 Ha dan nilai akresi mencapai 1,5 Ha. Nilai rata-rata abrasi pertahun mencapai 0,56 ha dan nilai akresi pertahun sebesar 0,58 ha. Abrasi terbesar terjadi pada tahun 2013-2014 mencapai 1,2 ha. Total nilai abrasi yang terjadi selama 5 tahun yaitu 2,8 ha dan total nilai akresi yang terjadi sebesar 2,9 ha. Proses abrasi dan akresi juga menyebabkan berubahnya panjang garis Pantai Ladong setiap tahunnya dan muara sungai menjadi salah satu faktor yang menyebabkan abrasi maupun akresi.
\end{abstract}

Kata Kunci: akresi; abrasi; Google earth

\section{Pendahuluan}

Pantai merupakan suatu daerah pertemuan daratan dan lautan dimana daerah tersebut dipengaruhi oleh parameter oseanografi yang saling berkaitan antara satu dengan yang lainnya. Faktor oseanografi seperti arus, pasang surut, gelombang dan angin mempengaruhi bentuk 
pantai seperti akresi dan abrasi. Hal ini terjadi karena transport sedimen terjadi secara terus menerus yang dapat menyebabkan perubahan garis pantai (Kristi dkk., 2014 dan Yuni dkk., 2014).

Perubahan pergeseran garis pantai pada umumnya tidak hanya disebabkan oleh faktor oseanografi, sungai, tektonik, vulkanik dan ekosistem pantai. Faktor manusia juga mempengaruhi perubahan garis pantai seperti pembangunan pelabuhan, pertambangan, pengerukan, perusakan vegetasi pantai, pertambakan, perlindungan pantai, reklamasi pantai, dan kegiatan wisata pantai (Hariyadi, 2011; Soraya dkk., 2012). Perubahan garis pantai merupakan salah satu proses yang dinamis, jika proses ini terus berlanjut maka akan mengganggu aktivitas disekitar pantai karena proses ini akan menyebabkan erosi ataupun abrasi di kawasan pantai tersebut (Christina, 2005).

Pantai Ladong terletak di Gampong Ladong, Aceh Besar. Gampong ini berbatasan dengan Selat Malaka pada sebelah utara, sebelah barat berbatasan dengan Gampong Durung, sebelah timur berbatasan dengan Gampong Ruyung, dan sebelah selatan berbatasan dengan Kuta Baro. Pantai Ladong dekat dengan lahan rehabilitasi hutan mangrove, tambak milik warga, dan tidak jauh dari pemukiman warga. Pantai ini dijadikan sarana untuk berwisata warga sekitar dan juga sebagai lokasi para nelayan untuk mencari nafkah, terlihat beberapa perahu nelayan disekitar pantai ini. Sehingga penelitian ini perlu dilakukan dengan tujuan sejauh mana perubahan garis pantai di sepanjang Pantai Ladong, yang dimulai dari tahun 2011 sampai dengan tahun 2015.

\section{Metode Penelitian}

\subsection{Waktu dan tempat}

Pengumpulan data garis pantai dengan metode citra satelit (google earth) dilakukan dari tahun 2011-2015 sedangkan pengumpulan data ground check dilakukan pada Agustus 2016. Lokasi penelitian yang dipilih terletak di Pantai Ladong, Kecamatan Mesjid Raya, Aceh Besar Provinsi Aceh (Gambar 1).

\subsection{Perangkat penelitian}

Penelitian ini menggunakan software SIG (Sistem Informasi Geografi) ArcMap 10.2 dan Global Mapper 11 dengan kemampuan image analysis untuk melakukan interprestasi visual, melakukan proses digitasi pada area garis pantai, mengelola data vektor dan pembuatan peta-peta tematik dan GPS (Global Positioning System) Garmin Rino $530 \mathrm{HCx}$ digunakan pada saat survei lapangan

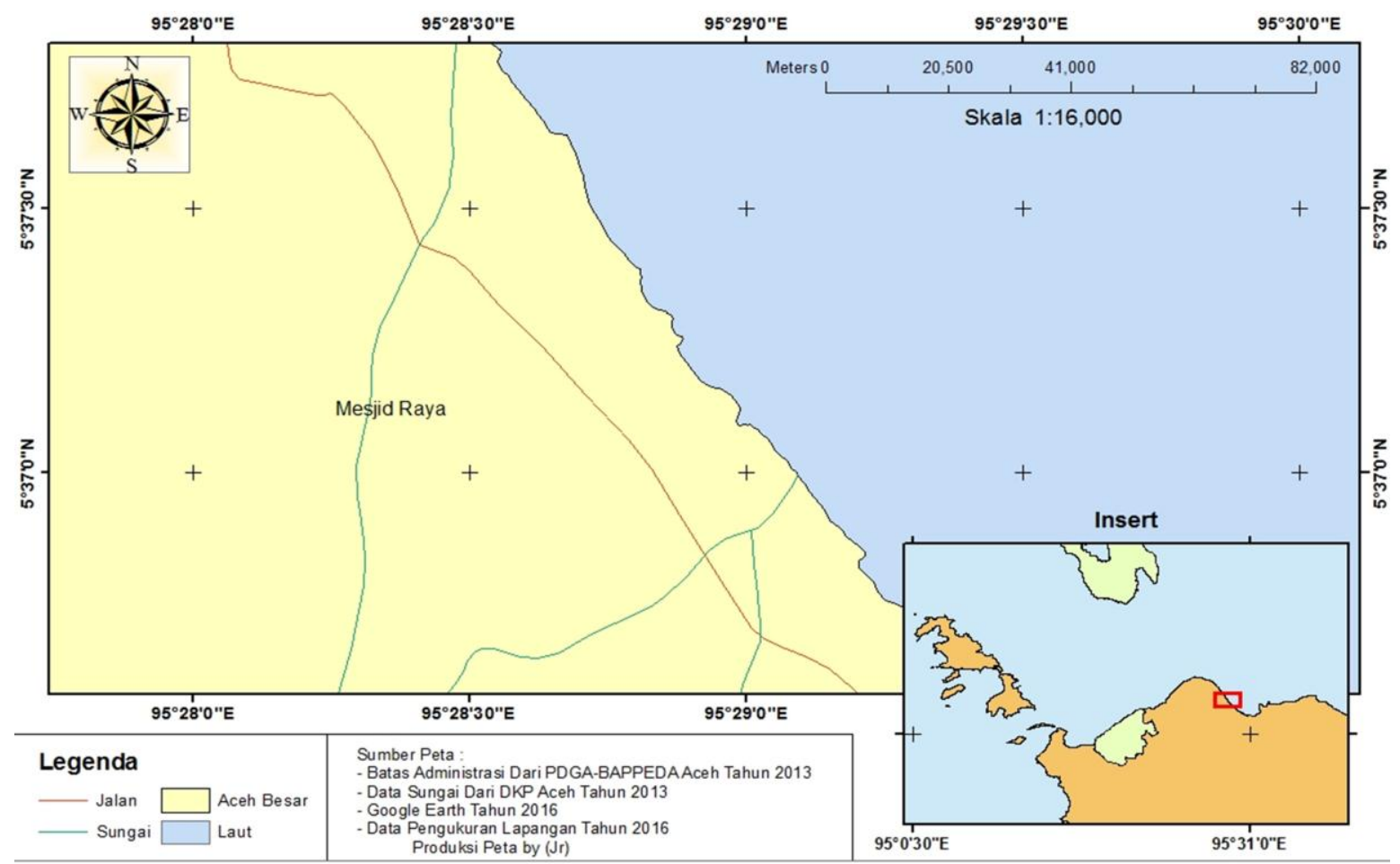

Gambar 1. Peta lokasi penelitian 
(Ground Check).

\subsection{Data penelitian}

Data penelitian berupa data yang diperoleh dari citra satelit resolusi menengah sampai tinggi. Data yang diolah yaitu citra satelit 1 Maret 2011, 6 Agustus 2012, 5 April 2013, 6 Januari 2014 dan 18 Januari 2015. Citra satelit yang di peroleh bersumber dari perangkat lunak Google Earth Pro dalam bentuk format file JPEG (Join Photographic Expert Group).

\subsection{Metode penelitian}

Metode yang digunakan berdasarkan analisis data Google Earth Pro ada beberapa tahap yang dilakukan yaitu tahap persiapan dan tahap pengolahan data yang disertai juga dengan tahap survei lapangan. Tahap persiapan merupakan tahap pengumpulan data input berupa data fotografi udara Pantai Ladong tahun 2011, 2012, 2013, 2014 dan 2015 yang berasal dari Google Earth. Pengolahan data citra dilakukan dengan menggunakan perangkat lunak SIG.

Tahap pengolahan meliputi: Koreksi Geometrik dilakukan dengan mencari sejumlah Ground Control Point (GCP) dikenali baik pada citra maupun pada acuan dan dicatat koordinatnya. Rektifikasi dilakukan minimal diperlukan 4 buah titik yang digunakan sebagai GCP. Penentuan titik-titik GCP diletakkan pada pojok kanan atas, pojok kiri atas, pojok kanan bawah dan pojok kiri bawah, Hal ini bertujuan agar citra dapat di rektifikasi secara merata. Lalu proses selanjutnya adalah digitasi yang bertujuan untuk mengubah format data raster ke format data vektor. Objek yang digitasi adalah garis pantai. Setelah tahap digitasi selesai selanjutnya adalah tahap tumpang susun (overlay) ke empat garis pantai tersebut. Hasil dari overlay tersebut merupakan perubahan garis pantai yang kemudian akan dianalisis perubahannya. Setelah melakukan tahap overlay maka dapat diketahui berapa luas perubahan garis pantai yang terjadi seperti perubahan luasnya pengikisan pantai (abrasi) dan luasnya penambahan pantai yang diakibatkan oleh pergerakan sedimen (akresi). Layouting dilakukan setelah proses analisis perubahan garis pantai selesai tahap berikutnya adalah layout (tampilan peta). Layout merupakan hasil akhir yang akan ditampilkan dalam bentuk peta yang menampilkan hasil garis perubahan pantai, legenda peta, teks skala, skala bar, arah mata angin, dan sumber peta.

Tahap survei lapangan (Ground Check) dilakukan dan difokuskan untuk mencari data. Data pedukung yang didapatkan di lapangan maupun instansi terkait seperti peta administrasi kecamatan, peta kabupaten Aceh Besar dan informasi lainnya yang mendukung data hasil penelitian. Hal ini dilakukan untuk mendukung keakuratan hasil intepretasi data Google Earth. Penentuan lokasi menggunakan metode pertimbangan (Purposive Sampling Method). Survei lapangan dilakukan pada setiap objek yang diidentifikasi (abrasi atau akresi) setelah pengolahan data dilakukan.

\section{Hasil dan Pembahasan}

\subsection{Analisis data Google earth}

Perubahan garis pantai dapat dilihat dengan pengolahan data analisis fotografi udara Google Earth Pro dengan cara tumpang susun (Overlay) untuk menghasilkan perbandingan garis pantai tahun 2011, 2012, 2013, 2014 dan 2015.

\subsection{Koreksi geometrik}

Koreksi geometrik dilakukan dengan menggunakan data foto udara yang diperoleh dari Google Earth Pro untuk memperoleh nilai yang sebenarnya pada bumi. Dalam melakukan retifikasi membutuhkan 4 titik GCP yang terletak pada pojok kanan atas, pojok kiri atas, pojok kanan bawah dan pojok kiri bawah pada data batas administrasi kecamatan yang bersumber dari PDGA BAPPEDA (Pusat Data Geospasial Aceh Badan Perencanaan Pembangunan Daerah) tahun 2013. Hal ini dilakukan karena data awal secara keseluruhan belum memiliki data spasial sehingga perlu di retifikasi. Tingkat akurasi koreksi geometrik dalam bentuk standar deviasi yang sering disebut RMSE (Root Mean Square Error) merupakan tingkat kesalahan antara koordinat dasar dengan koordinat yang telah di retifikasi, dan nilai RMSE harus berada dibawah 1 pixel, sehingga data tersebut tidak disebut error. Nilai RMSE seluruh data foto udara yang telah dikoreksi geometrik adalah 0 (nol). 


\subsection{Digitasi dan tumpang susun (overlay)}

Proses digitasi pantai dilakukan dengan cara polyline pada foto udara Google Earth tahun 2011, 2012, 2013, 2014, dan 2015. Skala yang digunakan dalam proses digitasi adalah 1:1.250 untuk menghasilkan tingkat akurasi yang tinggi antara batas air dan daratan. Hasil digitasi garis pantai seperti yang terlihat pada Gambar 2.

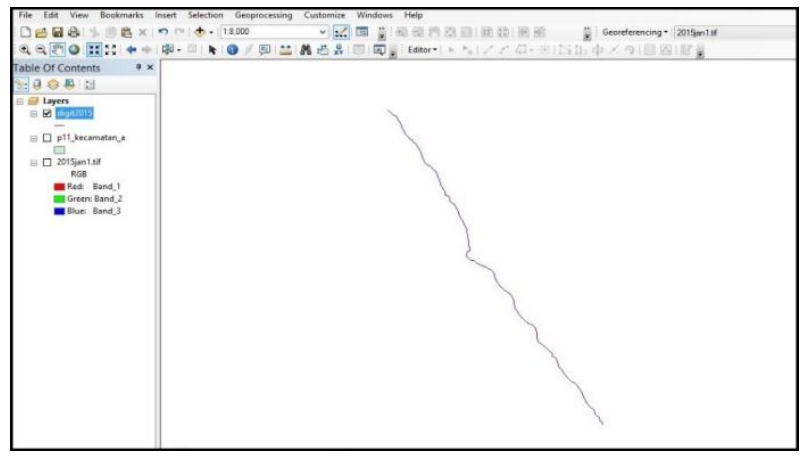

Gambar 2. Hasil digitasi garis pantai

Proses tumpang tindih (overlay) pada data tahun 2011, 2012, 2013, 2014, dan 2015. Proses ini dilakukan untuk melihat perbandingan garis pantai dari setiap data yang dimiliki (Gambar 3). Symmetrical Difference merupakan suatu menu yang terdapat pada Arctoolbox overlay yang berfungsi untuk melihat nilai abrasi dan akresi.

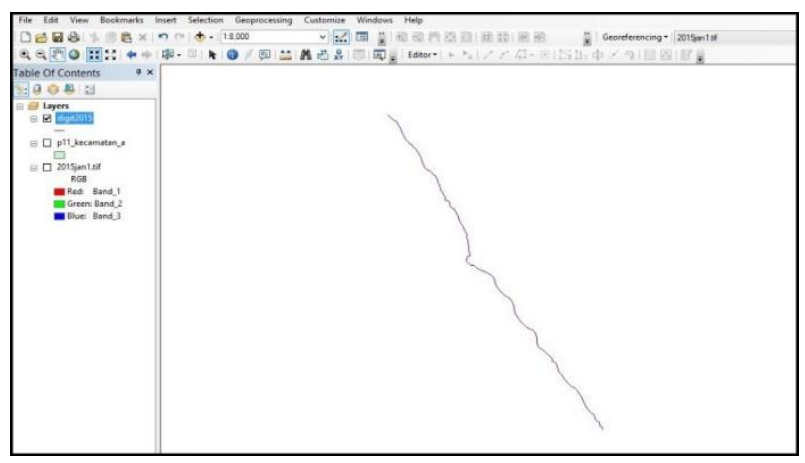

Gambar 3. Tumpang susun (overlay)

\subsection{Survei lapangan (ground check)}

Survei lapangan dilakukan untuk mendukung keakuratan hasil interpretasi data Google Earth. Survei lapangan dilakukan dengan mengambil 4 titik pada wilayah yang dapat mewakili area akresi maupun abrasi (Gambar 4) yang pada Agustus 2016. Pada titik 1 (5 $5^{\circ} 37^{\prime} 04.8^{\prime \prime} \mathrm{N}-95^{\circ} 29^{\prime}$ 02.1" E) merupakan daerah lahan terbuka, pohon kelapa pada daerah ini berjarak $\pm 5 \mathrm{~m}$ dari garis pantai. Pada titik 2 (5 $37^{\prime} 12.5^{\prime \prime} \mathrm{N}$ - 95을 $28^{\prime} 56.4^{\prime \prime} \mathrm{E}$ ), pantai akan mengalami kemunduran yang sangat jauh pada saat surut karena titik 2 tidak terlalu jauh dari muara sungai sehingga terjadinya penumpukan sedimentasi, pepohonan juga berjarak $\pm 5 \mathrm{~m}$ dari garis pantai. Pada titik $3\left(5^{\circ} 37^{\prime}\right.$

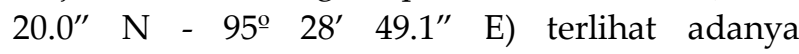
sedimentasi pada saat surut karena titik 3 berada di muara sungai dan sangat dekat dengan hutan mangrove. Pada titik 4 (5 $37^{\prime} 33.4^{\prime \prime} \mathrm{N}-95^{\circ} 28^{\prime} 44.0^{\prime \prime}$ E) hanya terdapat barisan pohon cemara, dan bukan merupakan daerah yang sering dikunjungi warga, ombak pada titik ini sangat kuat pada saat melakukan ground check.

\subsection{Layout}

Proses layout merupakan tahapan terakhir dari seluruh proses pengolahan data, output dari proses ini berupa peta perubahan garis pantai. Skala yang digunakan dalam menampilkan peta output adalah 1:6000. Dalam peta ini ditampilkan hasil garis pantai tahun 2011 hingga 2015, legenda peta, teks skala, skala bar, arah mata angin, dan sumber peta (Gambar 5).

\subsection{Panjang garis pantai dan luas pesisir}

Panjang garis pantai dan luas pesisir dapat berubah seiring berjalannya waktu, perubahan itu dapat terjadi akibat faktor alam seperti gelombang, ombak, sedimentasi dan juga manusia dapat menjadi faktor dari perubahan fisik pantai.

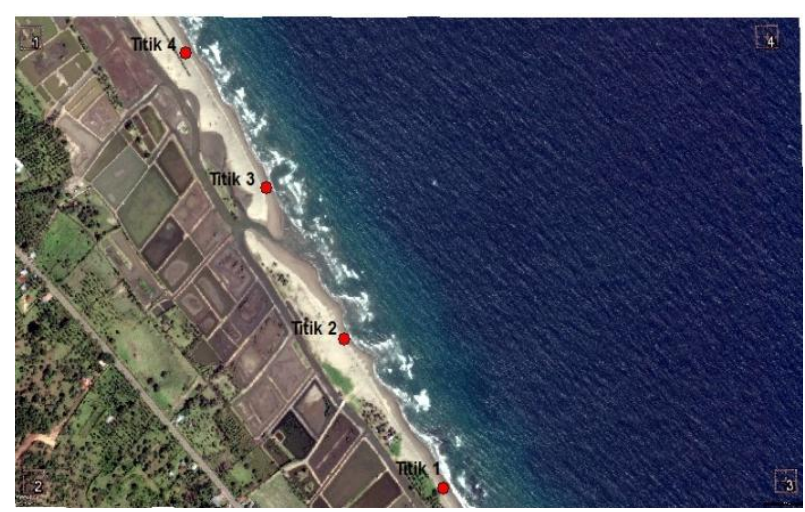

Gambar 4. Titik ground check

Tabel 1 menunjukkan perubahan luas pesisir pantai setiap tahunnya selalu berubah. Pada tahun 2011 luas pesisir pantai 35,40 ha, lalu pada tahun 2012 menjadi 34,71 ha yang disebabkan karena terjadinya abrasi. Tahun 2013 dan tahun 2014 terlihat terjadinya akresi yang menyebabkan 


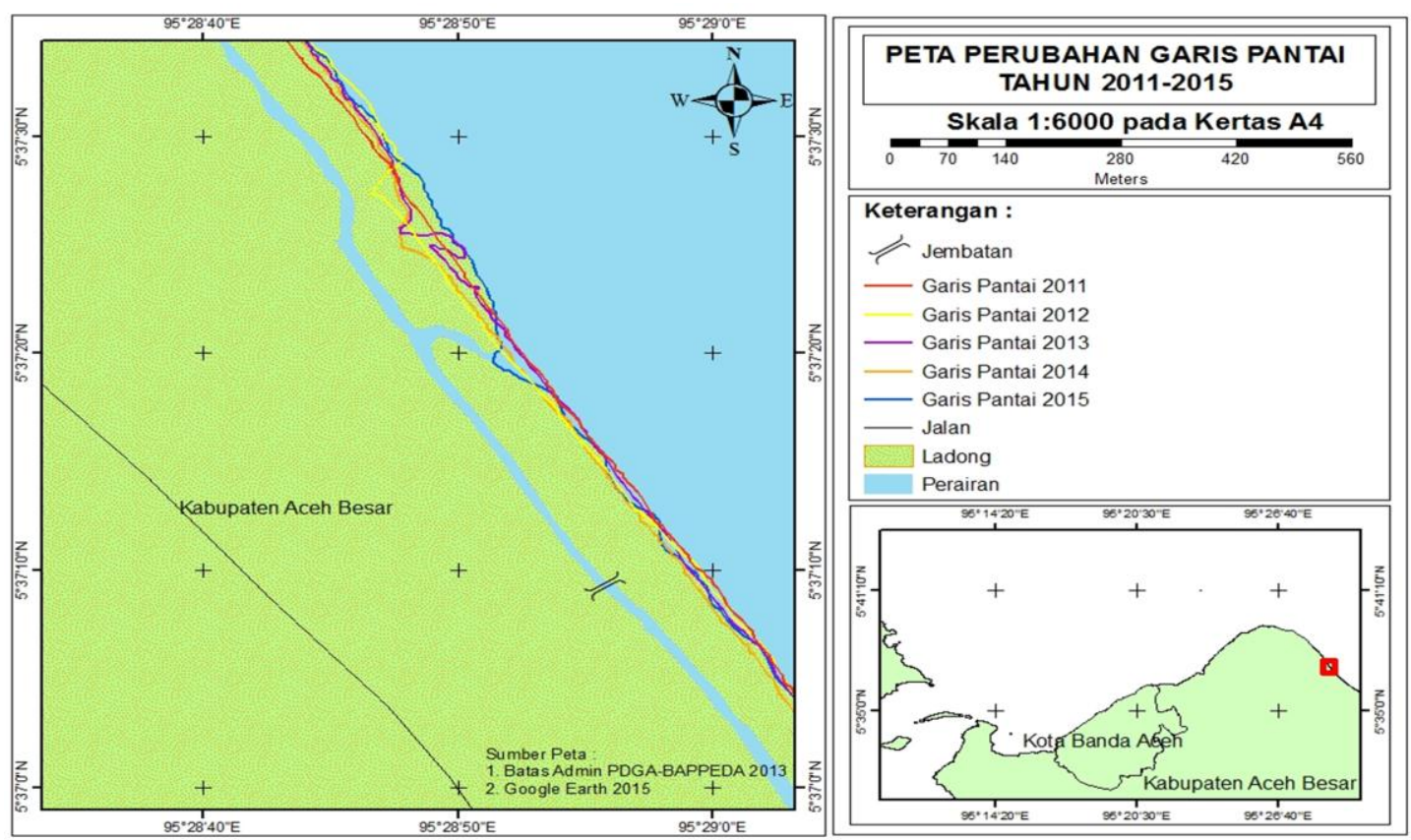

Gambar 5. Peta layout perubahan garis pantai tahun 2011-2015

penambahan garis pantai yang mana luas pesisir pantai semula 35,24 ha menjadi 35,52 ha. Tahun 2015 terjadi pengurangan pesisir pantai yang hanya sangat sedikit sehingga luas pesisir pantai tahun 2015 adalah 35,46 ha. Panjang garis pantai setiap tahunnya juga berubah-ubah tetapi tidak ada perubahan yang sangat signifikan, hanya terjadi perubahan kecil setiap tahunnya. Garis pantai terpanjang ialah pada tahun 2013 dengan panjang $1327,80 \mathrm{~m}$ dan yang terpendek pada tahun 2011 dengan panjang 1198,09 m.

\section{Tabel 1}

Panjang garis pantai dan luas pesisir pantai.

\begin{tabular}{ccc}
\hline Tahun & Garis Pantai $(\mathrm{m})$ & Luas Pesisir Pantai (ha) \\
\hline 2011 & 1198,09 & 35,40 \\
2012 & 1210,35 & 34,71 \\
2013 & 1327,80 & 35,24 \\
2014 & 1206,84 & 35,52 \\
2015 & 1232,78 & 35,46 \\
\hline
\end{tabular}

\subsection{Abrasi dan akresi}

Analisis perubahan garis pantai dapat dilakukan dengan hal sederhana, menggunakan teknik tumpang tindih (overlay) antara polygon daratan pantai pada data yang diperoleh dari Google Earth tahun 2011, 2012, 2013, 2014, dan 2015. Dengan menggunakan teknik ini laju perubahan abrasi dan akresi pada suatu kawasan pantai dapat diperkirakan dalam satuan ha/tahun. Nilai abrasi dan akresi dapat diketahui dari Tool Symmetrical Difference pada Arctoolbox Overlay.

Tabel 2 menunjukan bahwa setiap tahunnya pantai mengalami perubahan baik itu abrasi maupun akresi. Tahun 2011-2012 terjadi abrasi sebesar 1,1 ha dan 0,5 ha akresi. Tahun 2012-2013 abrasi dan akresi yang terjadi tidak sebesar yang terjadi pada tahun 2011-2012, abrasi yang terjadi pada periode ini sebesar 0,3 ha dan akresi sebesar 0,8 ha. Tahun 2013-2014 abrasi yang terjadi sebesar 1,2 ha, ini merupakan abrasi yang terbesar dalam kurun waktu 5 tahun dan akresi yang terjadi sangat kecil hanya 0,1 ha yang terjadi pada muara sungai. Tahun 2014-2015 abrasi yang terjadi hanya 0,2 ha dan akresi yang terjadi merupakan akresi terbesar dalam kurun waktu 5 tahun yaitu sebesar 1,5 ha.

Perubahan garis pantai abrasi terjadi akibat adanya arus laut dan ombak laut yang terus menerus menghantam bibir pantai. Akresi pantai disebabkan oleh penumpukan sedimen yang berasal dari daratan yang terendapkan di pantai terutama di muara sungai. Degradasi garis pantai juga dapat disebabkan oleh angin, arus, hujan, gelombang dan juga akibat aktivitas manusia (Tarigan, 2007). Hasil peta layout pertahun dapat menunjukan bahwa pada tahun 2011-2012 hampir $50 \%$ pantai mengalami abrasi dan pada tahun 2012-2013 terjadi hal yang sebaliknya, hampir sepanjang pantai mengalami akresi. Pada tahun 


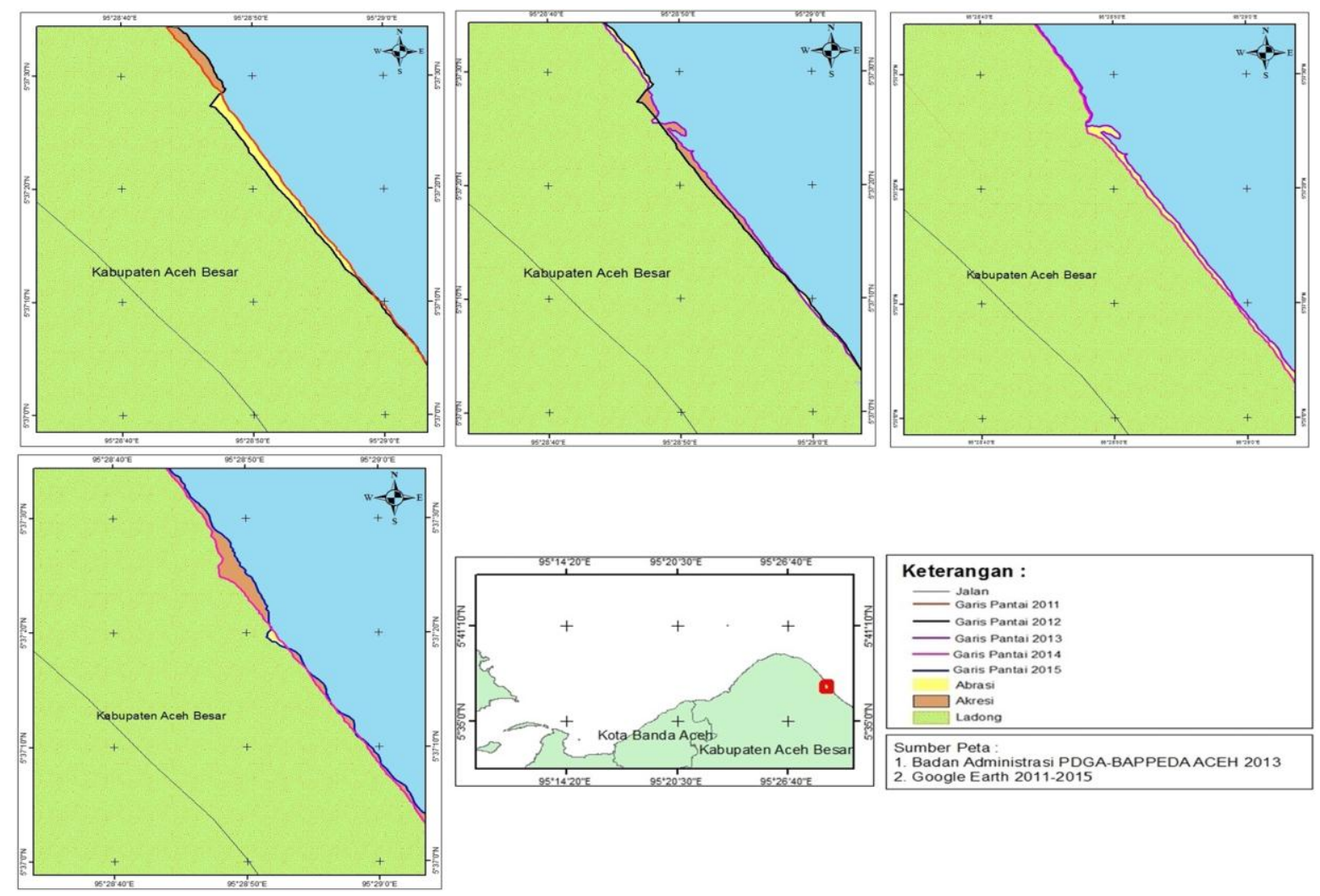

Gambar 6. Peta perubahan garis pantai pertahun dari Tahun 2011 sampai 2015

2013-2014 pantai mengalami abrasi kembali yang hampir terjadi di sepanjang pantai.

\section{Tabel 2}

Rata-rata perubahan pertahun (abrasi dan Akresi) garis pantai.

\begin{tabular}{ccc}
\hline Tahun & Akresi (ha) & Abrasi (ha) \\
\hline $2011-2012$ & 0,5 & 1,1 \\
$2012-2013$ & 0,8 & 0,3 \\
$2013-2014$ & 0,1 & 1,2 \\
$2014-2015$ & 1,5 & 0,2 \\
\hline Total luasan abrasi-akresi & 2,9 & 2,8 \\
Rata-rata pertahun & 0,56 & 0,58 \\
\hline
\end{tabular}

Tahun 2014-2015 terjadinya akresi hampir di sepanjang pantai, dan abrasi terjadi hanya di sekitar muara sungai kecil. Menurut Rizal (2002) bahwa abrasi terjadi secara alamiah maupun artifisial. Akresi alamiah merupakan penambahan lahan oleh kerja alamiah pada gisik karena pengendapan material. Sedangkan akresi artifisial merupakan penambhan lahan kerja karena manusia, seperti halnya akresi karena groin, breakwater atau beach fill yang disebabkan oleh alat-alat mekanik. Peta perubahan garis pantai selama 5 tahun dapat dilihat pada Gambar 6.
Proses abrasi maupun akresi yang terjadi di Pantai Ladong pada umumnya terjadi karena faktor alami jika dilihat dari kondisi fisik area penelitian, karena area pantai ini termasuk sepi, terlihat dari rumah warga yang jauh dari pesisir pantai. Akresi banyak terjadi pada muara sungai kecil di dekat lahan rehabilitasi hutan mangrove. Letak geografis Pantai Ladong menjadi salah satu faktor, arah arus yang datang dari arah tenggara menuju barat laut menyebabkan perubahan garis pantai, baik pada saat terjadinya muson barat maupun pada saat muson timur hal ini sesuai dengan pernyataan Rizal et al. (2012) bahwa Pergerakan massa air Selat Malaka pada saat muson barat massa air permukaan terbawa masuk ke arah laut Andaman dan pada saat muson timur massa air permukaan bergerak dari utara menuju ke laut Andaman.

Penambahan atau pengurangan garis pantai pada Tabel 3, ditandai dengan simbol minus (-) dan plus (+). Nilai perubahan garis pantai dapat di ketahui setelah melakukan proses overlay. Nilai pengurangan kearah daratan yang terjadi pada tahun 2011-2012 sebesar (-) 22,7 $\mathrm{m}$ dan penambahan sebesar (+) 7,3 $\mathrm{m}$. Tahun 2012-2013 pengurangan terjadi sebesar (-) $8,3 \mathrm{~m}$ dan penambahan sebesar (+) $21 \mathrm{~m}$. Tahun 2013-2014 
pengurangan sebesar (-) 22,5 $\mathrm{m}$ dan penambahan sebesar (+) 0,5 m. Tahun 2014-2015 pengurangan terjadi sebesar (-) 6,3 $\mathrm{m}$ dan penambahan sebesar (+) 29,3 m.

Perubahan garis pantai secara umum berlangsung dengan lambat tetapi jika didukung dengan faktor baik alami maupun tidak, perubahan garis pantai akan terjadi dengan sangat cepat seperti penelitian yang dilakukan oleh Yuni dkk. (2015) di perairan Pusong Kota Lhokseumawe. Berdasarkan penelitian Solihuddin (2011) di pesisir Padang Pariaman, upaya penanggulangan abrasi secara alamiah (back to nature) perlu dilaksanakan seperti penanaman pohon kelapa, dan pohon cemara di sekitar pantai untuk mengurangi dampak abrasi yang lebih besar. Penanaman mangrove disekitar pantai dapat membantu mengurangi dampak akresi.

Tabel 3

Pengurangan (-) garis pantai ke arah daratan dan penambahan $(+)$ garis pantai ke arah lautan.

\begin{tabular}{ccc}
\hline \multirow{2}{*}{ Tahun } & \multicolumn{2}{c}{ Rata-rata perubahan garis pantai } \\
\cline { 2 - 3 } & Pengurangan $(\mathrm{m})$ & Penambahan $(\mathrm{m})$ \\
\hline $2011-2012$ & $(-) 22,3$ & $(+) 7,3$ \\
$2012-2013$ & $(-) 8,3$ & $(+) 21$ \\
$2013-2014$ & $(-) 22,5$ & $(+) 0,5$ \\
$2014-2015$ & $(-) 6,3$ & $(+) 29,3$ \\
\hline
\end{tabular}

\section{Simpulan}

Luas pesisir Pantai Ladong dari tahun 2011-2015 setiap tahunnya mengalami perubahan, dimana pada tahun 2012 terjadi penambahan pesisir terbesar dan tahun 2013 terjadi pengurangan pesisir pantai terbesar dengan persentase $0,7 \%$. Luas pesisir Pantai Ladong selalu mengalami pengurangan sejak tahun 2012 dan jika terjadi penambahan tidak terlalu besar, dengan luas awal sebesar 34,71 ha menjadi 35,24 ha. Total nilai akresi yang terjadi pada Pantai Ladong secara keseluruhan lebih besar dibandingkan dengan total nilai abrasi yang terjadi dalam kurun waktu 5 tahun. Perubahan garis Pantai Ladong secara umum disebabkan oleh faktor alam, salah satunya muara sungai yang menyebabkan terjadinya sedimentasi.

\section{Daftar Pustaka}

Christina, J. (2005). Studi perubahan garis pantai Selatan Teluk Ambon Luar dengan Metode Komar dan Bikjer. Jurnal teknologi, 2(2), 23-28.

Hariyadi. (2011). Analisis perubahan garis pantai selama 10 tahun menggunakan cedas (coastal engineering design and analysis system) di perairan Teluk Awur pada skenario penambahan bangunan pelindung pantai. Buletin oseanografi marina, 1(1), 82-94.

Kristi, L., Saputro, S., \& Hariadi. (2014). Perubahan garis pantai Larangan, Kabupaten Tegal melalui pendekatan model genesis (generalized model for simulating shoreline change). Jurnal oseanografi, 3(1), 5256.

Rizal, I. (2002). Dampak perubahan penggunaan lahan sepanjang Pantai Ujong Blang Lhokseumawe terhadap pemunduran garis pantai. Jurnal ekoton, 2(1), 25-30.

Rizal, S., Damm P., Wahid, M. A., Sundermann, J., Ilhamsyah, Y., Iskandar, T., \& Muhammad. (2012). General circulation in the Malacca strait and Andaman sea: a numerical model study. American journal of enviromental science, 8(5), 475-488.

Solihuddin, Tb. (2011). Karakteristik pantai dan proses abrasi di pesisir Padang Pariaman, Sumatera Barat. Globe, 13(2), 112-120.

Soraya, D., Suhara, O., \& Taofiqurohman, A. (2012). Perubahan garis pantai akibat kerusakan hutan mangrove di Kecamatan Blanakan dan Kecamatan Legonkulon, Kabupaten Subang. Jurnal perikanan dan kelautan, 3(4), 355-364.

Tarigan, M. S. (2007). Perubahan garis pantai di wilayah pesisir perairan Cisadane, Provinsi Banten. Makara sains, 11(1), 49-55.

Yuni, N., Setiawan, I., \& Affan, M. (2015). Analisis perubahan garis pantai Pusong Kota Lhokseumawe Provinsi Aceh tahun 2005-2014 menggunakan data penginderaan jauh. Jurnal rona lingkungan hidup, 8(2), 34-40.

Yuni, S. M., Setiawan, I. \& Maufiza, O. (2014), Solusi analitik perubahan garis pantai menggunakan transformasi Laplace. Jurnal gradien, 10(2), 1005-1013. the terms and conditions of the Creative Commons Attribution license (http://creativecommons.org/licenses/by/3.0/). 